\title{
Az egészségügyi kártérítési perek kommunikációs vonatkozásai
}

\author{
Pilling János dr. ${ }^{1}$ - Erdélyi Kamilla dr. ${ }^{2}$ \\ 'Semmelweis Egyetem, Általános Orvostudományi Kar, Magatartástudományi Intézet, Budapest \\ ${ }^{2}$ Semmelweis Egyetem, Mentálhigiéné Intézet, Budapest
}

\begin{abstract}
Az egészségügyi ellátás során tapasztalt problémák miatt egyre több a kártérítési per, azonban egyes orvosokat nagyobb valószínúséggel, illetve gyakrabban perelnek be, mint másokat. Számos kutatás igazolja, hogy ennek az okai között a perbe fogott orvosok kapcsolati, kommunikációs készségeinek a hiányosságai játsszák a legfóbb szerepet többek között a beteg kikérdezésének, meghallgatásának, az információk átadásának az elégtelenségei. Kiemelt jelentősége van a kommunikációnak a betegellátás során bekövetkező hibák kezelése során is. A legtöbb orvos a hiba eltitkolására törekszik, ez azonban a beteg állapotának további romlásához vezethet. Azokban az intézményekben, amelyekben a hibákkal kapcsolatos nyílt kommunikációt - az egészségügyi teamen belül és a beteg, illetve a hozzátartozó felé egyaránt - bevezették, csökkent a kártérítési perek száma. A kártérítési perek az orvosok számára is nagy megterhelést jelentenek, ezért szükség lenne az orvosok támogatási lehetőségeinek kialakítására, kommunikációs képzésekre, valamint arra, hogy a jogi környezet is támogassa az ellátási hibák nyílt kommunikációját. Orv. Hetil., 2016, 157(17), 654-658.
\end{abstract}

Kulcsszavak: orvosi kártérítési per, kommunikáció, hibák közlése

\section{Aspects of communication regarding medical malpractice suits}

Due to problems experienced in health care, there is an increased amount of malpractice suits nowadays. Nevertheless, some physicians are more likely to be sued, or more frequently sued, than others. Numerous studies indicate that this phenomenon fundamentally results from a lack of interpersonal and communication skills on the part of the sued doctor, namely, deficiencies in questioning the patient, listening, conveying information, etc. Communication is of pivotal importance in patient care vis-à-vis medical errors as well. The majority of physicians aim to conceal the error, albeit this may lead to further deterioration of the patient's condition. In institutions where open communication regarding errors was introduced within the medical team and toward the patient and their family alike, the number of malpractice suits decreased. It is crucial to establish a means of support for doctors, and to promote communication trainings, as well as a supportive legal environment.

Keywords: malpractice suits, communication, conveying errors

Pilling, J., Erdélyi, K. [Aspects of communication regarding medical malpractice suits]. Orv. Hetil., 2016, 157(17), 654-658.

(Beérkezett: 2016. február 26.; elfogadva: 2016. március 17.)

A kártérítési perek gyökerei a XVIII. századig nyúlnak vissza: ebben az időszakban alakították ki az orvosok felelősségének jogi kereteit Nyugat-Európában és az Egyesült Államokban. Egészen az 1970-es évek közepéig azonban ritkaságnak számítottak az ilyen perek [1]. A XX. századi orvostudomány ugrásszerű technikai fejlődése, az orvos-beteg kapcsolat átalakulása és az egész- ségügyi ellátás szolgáltatás jellegének kialakulása azt eredményezte, hogy az Amerikai Egyesült Államokban az 1970-es évek közepén rövid idő alatt jelentősen megnövekedett az egészségügyi kártérítési perek száma [2]. Hazánkban ugyanez a folyamat némileg megkésve, a rendszerváltást követően zajlott le, azóta azonban a kártérítési perek száma jelentős növekedést mutat [3]. 


\section{Az orvosi kommunikáció szerepe a kártérítési perek indításában}

A kártérítési perek növekvő száma ellenére valójában a legtöbb ellátási hiba nem eredményez pert. Több vizsgálat egybehangzó eredménye szerint a nem megfelelő ellátásra visszavezethető hibáknak csak $1-2 \%$-a végződik perrel. A legtöbb páciens, aki ellátása során hibát tapasztal, ignorálja azt, vagy más úton fejezi ki elégedetlenségét (például a betegjogi képviselőhöz fordul), esetleg orvost, illetve intézményt vált [4]. Figyelemre méltó továbbá, hogy szakmától függő́n az orvosoknak egy kisebb csoportja, 2-8\%-a között oszlik meg a kártérítési összegek 50\%-a. Amennyiben az adatokat nem szakmák szerint, hanem a teljes orvostársadalomra vonatkoztatva szemléljük, az eredmény még karakterisztikusabb: a lezárt perekben megítélt kártérítések összegének $85 \%$-a az orvosok csupán 3\%-a között oszlik el [5]. Ezek az adatok arra utalnak, hogy a legtöbb beteg még akkor sem indít pert, ha ellátási hibát tapasztal, másrészt pedig egyes orvosokat nagyobb valószínűséggel, illetve többször perelnek be a betegeik, mint másokat. Milyen okok állhatnak ennek a hátterében?

Számos vizsgálat hasonlította össze a beperelt orvosokat azokkal, akik ellen nem indítottak pert. Logikusnak tünne, hogy azoknak az orvosoknak kell bíróság elé állniuk, akik szakmailag rosszabbak, mint a társaik, a vizsgálatok azonban ezt a feltételezést cáfolják: a beperelt orvosok végzettsége, szakmai ismeretei, technikai készségei, a betegellátás objektív paraméterei nem rosszabbak azoknál, akik ellen nem indítottak pert. A két csoport között nem találtak különbséget a kezelt páciensek betegségének súlyossága és a betegek karaktere tekintetében sem $[5,6]$.

A kutatások azonban újra és újra különbséget jeleztek a két csoport között az orvosok kommunikációs stílusában [7-11]. A beperelt orvosokra egyaránt jellemző volt, hogy kevésbé hallgatták végig pácienseik panaszait [10], éreztették, hogy kevés idejük van rájuk [7] és túl kevés információt adtak nekik [7,9-11]. A kevésbé perelt orvosok ezzel szemben többet törődtek azzal, hogy a vizsgálat menete átláthatóbb legyen a páciens számára, szívesebben hallgatták meg őket, többször használták a humor eszközeit, több és tisztább magyarázatot adtak a pácienseknek, bátorították óket kérdések feltevésére [8]. A verbális kommunikáció mellett a perek indítását befolyásolhatja az orvos nonverbális kommunikációja is. Egy vizsgálat során önkéntesek egy rutin orvosi konzultáció csupán 20 másodpercnyi hangfelvételéből megbízhatóan tudták jelezni, hogy az adott sebésznek volt-e korábban múhibapere vagy sem - többek között a beperelt sebészek hangjának dominánsabb jellege alapján [12].

\section{Az orvosi hibák, tévedések közlése}

Az orvos-beteg kapcsolat, a kommunikáció minősége mellett az orvosi hibák kezelésének módja is gyakran vezet per indításához.
Az orvosi hibákkal kapcsolatos attitúdök az Egyesült Államokban és Nyugat-Európában sokat változtak az elmúlt évtizedekben. A régebbi szemlélet szerint egy jó orvos nem követhet el hibát. Az orvosi hiba elkövetése szégyennek számított, így az orvosok a hiba eltitkolására törekedtek. Amennyiben a hiba mégis napvilágra került, az orvosnak súlyos retorziókkal kellett szembenéznie (beleértve akár az elbocsátását is), szakmáján belül kiközösítetté vált. A szakirodalomban gyakran használják erre a korszakra a „rossz alma” hasonlatot: a hibás almát el kellett távolítani az egészségesek közül. A hallgatás, a szégyen és a hibáztatás szemlélete azonban elavult. A mai szemlélet szerint egy orvos több évtizedes pályafutása során elkerülhetetlenek a hibák, ám ezek számát minimalizálni kell rendszerszintû́ megelőző, támogató és ellenőrző módszerekkel. Ennek következtében, ha az egészségügyi ellátás során hiba történik, akkor az minden esetben rendszerszintü problémákat is jelez. A hibákkal éppen ezért a mai szemlélet szerint nyíltan kell foglalkozni. Egy hiba bekövetkezése esetén a teljes orvosi teamnek együtt kellene dolgoznia azon, hogy a hiba következményeit elhárítsa vagy minimalizálja - a hibában leginkább érintett orvos így a kiközösítés helyett támogatásban részesül. A hibák kivizsgálásának legfó́bb célja a rendszerszintű hiányosságok feltárása és kijavítása, annak érdekében, hogy hasonló hiba ne következzen be többé. Az orvosi hibákkal kapcsolatos modern szemlélet tehát a nyílt kommunikáció, a támogatás, a betegbiztonság szempontjait helyezi előtérbe. Ennek a szemléletnek az elterjedése és gyakorlati alkalmazása a betegeknek, a hibában leginkább érintett orvosoknak és az egészségügyi intézményeknek egyaránt érdeke [13-15].

Az orvosi hibákkal kapcsolatos szemlélet átalakulásának megfelelően változás zajlik az orvosok attitúdjeiben is a hibák, tévedések közlésével kapcsolatban. A „hallgatás kultúrája" helyett egyre több orvos véli úgy, hogy ha egy orvos hibázik, akkor erről a beteget is tájékoztatni kell. Egy gyermekorvosok körében végzett vizsgálatban például azt találták, hogy egy súlyos hibát az orvosok 97\%-a, egy kisebb hibát 90\%-a, egy egészségkárosodást nem okozó tévedést pedig 82\%-a tart közlendőnek [16]. A témakör szakirodalmát áttekintő szisztematikus review eredményei is azt mutatják, hogy az orvosok az attitúdök szintjén általában támogatják az orvosi hibák nyílt közlését [17].

Hasonló a betegek véleménye is - sőt ôk még nagyobb arányban várnák el orvosaiktól, hogy a hibákról tájékoztassák őket. Egy 499 szülő bevonásával végzett vizsgálat szerint a súlyos hibák közlését a résztvevók $99 \%$-a várja el [18]. Egy másik vizsgálatban a páciensek 98\%-a még a kisebb hibák közlését is fontosnak tartotta [19].

A mindennapi gyakorlatban azonban jelentős szakadék tátong az orvosok attitúdjei és tettei között. A vizsgálatok általában azt jelzik, hogy az orvosoknak legfeljebb az egyharmada beszél nyíltan az ellátás során elkövetett hibákról $[20,21]$. Egy gyakran idézett kutatásban 254 családorvost kérdeztek meg életük legna- 
gyobb hibájáról - mint kiderült, erről csupán az orvosok 24\%-a tájékoztatta a beteget vagy annak családtagjait [22]. A közlés elmaradásának hátterében számos ok található, egyéni szinten többek között a jogi következményektől való félelem, a szégyen érzete, a szakmai presztízsvesztés miatti aggodalom, az orvos-beteg kapcsolat megromlásától való félelem, a nehéz helyzetek kezelésével kapcsolatos kommunikációs készségek hiánya, szervezeti szinten a hibák kezelésének nem megfelelő szervezeti kultúrája, társadalmi szinten pedig az a jogi környezet, amely a hibákat nyíltan feltáró orvosokat súlyos következményekkel fenyegeti [15].

Kétségtelen, hogy számos érv szól a hibák nyílt közlése mellett és ellene is [23], ám a témakörben végzett, immár igen nagyszámú vizsgálat alapján egyértelmúen megállapítható, hogy jóval több haszonnal jár a nyílt közlés, mint az eltitkolás. A fentebb már említett érvek mellett a vizsgálatok arra is rámutatnak, hogy a nyílt közlést gátló hiedelmek esetenként tévesek. Vizsgálatok szerint például nem a hiba nyílt közlése, hanem éppen ellenkezőleg, a hiba eltitkolására való (gyakran eredménytelen) törekvés vezet az orvos-beteg kapcsolat súlyos megromlásához - ez a magatartás negatív érzelmeket vált ki, és növeli a jogi lépések valószínüségét [24]. Amint a hibák közlésére vonatkozó szisztematikus review tanulmányok $[17,25]$ eredményei is mutatják, a betegek ebben a helyzetben azt várják az orvostól, hogy beszéljen nyíltan az ellátás során bekövetkezett hibáról, mondja el, hogy mi történt, miért történt, mindez milyen hatást gyakorol(hat) az ő egészségi állapotára, mit fognak most tenni érte, továbbá az orvos fejezze ki sajnálkozását, s mondja el, milyen lépések megtételét tervezik annak érdekében, hogy mindez ne ismétlődhessen meg. Amennyiben ezek az elvárások nem teljesülnek, a betegek elégedetlenek lesznek, s gyakran éppen ez vezet per indításához. Egy kutatásban, amelyben 227, pert indított beteg, illetve hozzátartozó motivációit vizsgálták, arra az eredményre jutottak, hogy kevesebb mint 15\%-uk tartotta megfelelőnek az orvostól kapott tájékoztatást, a pert indítók 91\%-a jelölte meg a motivációi között, hogy magyarázatot szeretett volna kapni arra, mi történt, 67\%-a pedig azt, hogy nem vették figyelembe az érzelmeit [26].

Mindezen eredmények alapján 2001-ben a Joint Commission minőségbiztosítási szervezet az Egyesült Államokban megalkotta az első, országos hatáskörü közlési protokollt, amely elöírja a nemkívánatos eseményekrôl szóló nyílt tájékoztatást. Ennek bevezetését a szervezet a kórházak akkreditációja során innen kezdve figyelembe vette. Nem sokkal később Ausztráliában, majd az Egyesült Királyságban is átfogó programokat indítottak az egészségügyi ellátás során bekövetkező nemkívánatos események nyílt közlése érdekében [27].

Több kutatás is vizsgálta a nyílt közlést támogató programok hatásait. Az Egyesült Államokban az első ilyen programot Lexingtonban, a Veterans Administration Medical Centerben vezették be, 1999-ben. Ezt követően 13 év alatt 170 incidenst kezeltek ilyen szemlélet- tel, ezek közül csupán 3 esetben indítottak pert a kórház ellen. A szervezet a legmagasabb kártérítési összeget fizető intézmények közül a program bevezetése után a legalacsonyabb összeget fizetők közé került át [28]. A program nyomán „Sorry Works! Coalition” néven létrejött egy orvosokból, jogászokból, biztosítási szakemberekből és páciensekből álló szervezet (honlapjuk: http:// www.sorryworks.net), amely a nyílt közlés elveinek és gyakorlatának terjesztését, az ezzel kapcsolatos akadályok leküzdését tekinti legfőbb céljának [29].

A Michigani Egyetemen 2001-ben megkezdték a Joint Commission ajánlásainak alkalmazását, s 2003-tól már kivétel nélkül minden elkövetett hibát nyíltan közöltek a páciensekkel. Bár a program kapcsán sokan a perek számának növekedésére számítottak, ennek az ellenkezője történt. 2001-ben még 121 új per indult az intézmény ellen, 2006-ban már csak ennek a fele, 61. 2001ben összesen 262 per volt folyamatban az intézmény ellen, 2007-ben már csak 83 [30]. A nyílt közlési program első hat évében (összehasonlítva az előző hat év adataival) az egyetem orvosi hibákkal kapcsolatos költségei (perköltségek és peren kívüli egyezségek költségei együttesen) összesen 61\%-kal csökkentek [31].

\section{Megbeszélés}

A jelen tanulmányban idézett vizsgálatok meggyőzően bizonyítják, hogy az orvos-beteg kapcsolat minőségének, a megfelelő orvosi kommunikációnak kiemelt szerepe van a betegbiztonság javításában és a kártérítési perek megelőzésében. Az orvosi hibákkal kapcsolatos korábbi szemlélet, a hallgatás kultúrája, a titkolózás, a kiközösítés nem jelent megoldást a problémákra, sőt súlyosbítja azokat. A nyílt kommunikáció, a támogató magatartás minden érintett (orvos, beteg és intézmény) számára előnyösebb lenne. Ez a változás az Egyesült Államokban és Nyugat-Európában már megindult - Magyarországon azonban jelenleg még általános gyakorlatnak tekinthető a törekvés az orvosi hibák eltitkolására.

Ahhoz, hogy a szemléletben és a gyakorlatban egyaránt változás történhessen, több mindenre is szükség lenne. Mindenekelőtt az orvosok kommunikációs képzésének fejlesztésére. Az ilyen irányú képzések szükségességére és hatékonyságára számos tanulmány hívja fel a figyelmet [32-34].

Az orvosi kommunikációs képzések területén már Magyarországon is vannak pozitív változások. 1993-ban a budapesti orvosi egyetemen kötelező tantárgyként vezették be a kommunikáció oktatását. Ma már - különböző keretek között - valamennyi hazai orvosi egyetemen a képzés része a kommunikációs ismeretek elsajátítása. A GYEMSZI (később: ENKK) 2014-2016 között szervezett továbbképzést gyakorló orvosok számára az orvosi hibák kommunikációjáról a Semmelweis Egyetemen orvosi kommunikáció oktatóinak részvételével. Ebben a programban összesen közel 700 orvos vett részt. Más 
képzések keretei között (például Szegeden) is sor került már az orvosi hibák kommunikációjának oktatására.

A szemléletváltás elősegítéséhez azonban további lépésekre is szükség lenne. Hasznos volna, ha a szakmai irányelvek integrálnák az adott szakterületeken az orvosbeteg kommunikációra vonatkozó kutatási eredményeket és ajánlásokat is. Hasznos lenne, ha Magyarországon is létezne az orvosi hibák közlésére vonatkozó szakmai irányelv - a Kanadai Betegbiztonsági Intézet már készített ilyen útmutatót [35]. Fontos lenne az is, hogy az egészségügyi intézmények rendelkezzenek az ellátási hibák közlésére vonatkozó protokollal [27]. Magyarországon itt még nem tartunk, ám ezeken a területeken is tapasztalhatók biztató jelek: a betegbiztonság kérdéseinek előtérbe kerülése (amit többek között a NEVES Betegbiztonsági Program létrejötte, a Magyar Betegbiztonsági Társaság megalakulása, betegbiztonsági konferenciák jeleznek) felszínre hozta az orvosi hibák kérdéskörét is.

Az orvosi hibák közlésével kapcsolatos szemlélet és gyakorlat megváltozásához szükség lenne továbbá a jogi környezet változására is. Az Egyesült Államok több tagállamában, Kanada több tartományában és Ausztráliában is hatályba léptettek már olyan jogszabályokat, amelyek az egészségügyi ellátás során történő hibák mielőbbi feltárását támogatják. Ezek a jogszabályok általában leszögezik, hogy a hibáról való tájékoztatás nem jelenti a felelősség elismerését, esetenként pedig kizárják azt, hogy az orvosi tájékoztatás kapcsán elhangzottakat a későbbi eljárásokban az orvos ellen felhasználhassák. Az események okainak, a felelősségnek a megállapítása így egy későbbi vizsgálat eredménye lehet, amely független az orvosi tájékoztatástól. Az ilyen jellegü jogszabályok eredményesen segíthetik a nyílt közlés terjedését [36, 37].

Ahhoz azonban, hogy a képzéseken megszerzett ismeretek, a szakmai protokollok előírásai és a jogszabályi lehetôségek a mindennapi gyakorlatba is beépüljenek, az egészségügyi intézményeknek maguknak kell olyan szervezeti kultúrát kialakítani, amely a betegbiztonság javítása érdekében támogatja a hibák nyílt kommunikálását [36].

Ezeknek az elveknek a megvalósítása esetén azok a páciensek, akiknek az ellátása során hiba történt, mielőbbi szakmai segítségben és támogatásban részesülhetnek. Mi lesz azonban azokkal az orvosokkal, akik szakemberként érintettek ebben a folyamatban? Ezek a helyzetek értelemszerüen nagyon megterhelőek az orvosok számára is, akik így egyfajta „második áldozatává” válnak az eseményeknek. A hibát elkövető, illetve beperelt orvosok támogatása külföldön is kezdeti stádiumban van [38], Magyarországon pedig jelenleg ilyen kezdeményezésről nincs tudomásunk. Az eltitkolás és a hibáztatás szemlélete helyett az intézmények nyílt, támogató szervezeti kultúrájának kialakítása azonban az orvosok támogatása szempontjából is fontos előrelépés lenne, így ez a szemléletváltás az orvosoknak, a betegeknek és az egészségügyi intézményeknek egyaránt érdeke lehet.
Anyagi támogatás: A közlemény megírása, illetve a kapcsolódó kutatómunka anyagi támogatásban nem részesült.

Szerzői munkamegosztás: P. J.: A tanulmány struktúrájának kidolgozása, a szakirodalom feldolgozása, a kézirat megszövegezése. E. K.: A szakirodalom feldolgozása, a kézirat megszövegezése. A kézirat végleges változatát mindkét szerző elolvasta és jóváhagyta.

Érdekeltségek: A szerzőknek nincsenek érdekeltségeik.

\section{Irodalom}

[1] Mohr, J. C.: American medical malpractice litigation in historical perspective. JAMA, 2000, 283(13), 1731-1737.

[2] Danzon, P. M.: The frequency and severity of medical malpractice claims: new evidence. Law Contemp. Probl., 1986, 49(2), 57-84.

[3] Dósa, Á.: Liability of health care providers. [Az orvos kártérítési felelőssége.] HVG-ORAC Lap- és Könyvkiadó, Budapest, 2004. [Hungarian]

[4] Huntington, B., Kubn, N.: Communication gaffes: a root cause of malpractice claims. Proc. (Bayl. Univ. Med. Cent.), 2003, 16(2), 157-161.

[5] Sloan, F. A., Mergenhagen, P. M., Burfield, W. B., et al.: Medical malpractice experience of physicians. Predictable or haphazard? JAMA, 1989, 262(23), 3291-3297.

[6] Entman, S. S., Glass, C. A., Hickson, G. B., et al.: The relationship between malpractice claims history and subsequent obstetric care. JAMA, 1994, 272(20), 1588-1591.

[7] Hickson, G. B., Clayton, E. W., Entman, S. S., et al.: Obstetricians' prior malpractice experience and patients' satisfaction with care. JAMA, 1994, 272(20), 1583-1587.

[8] Levinson, W., Roter, D. L., Mullooly, J. P., et al.: Physician-patient communication. The relationship with malpractice claims among primary care physicians and surgeons. JAMA, 1997, 277(7), 553-559.

[9] Adamson, T. E., Tschann, J. M., Gullion, D., et al.: Physician communication skills and malpractice claims. A complex relationship. West. J. Med., 1989, 150(3), 356-360.

[10] Hagihara, A., Tarumi, K.: Association between physicians' com municative behaviors and judges' decisions in lawsuits on negligent care. Health Policy, 2007, 83(2-3), 213-222.

[11] Hamasaki, T., Takehara, T., Hagihara, A.: Physicians' communication skills with patients and legal liability in decided medical malpractice litigation cases in Japan. BMC Fam. Pract., 2008, 9, 43.

[12] Ambady, N., LaPlante, D., Nguyen, T., et al.: Surgeons' tone of voice: a clue to malpractice history. Surgery, 2002, 132(1), 5-9.

[13] Cuschieri, A.: Nature of human error: implications for surgical practice. Ann. Surg., 2006, 244(5), 642-648.

[14] Guillod, O.: Medical error disclosure and patient safety: legal aspects. J. Public Health Res., 2013, 2(3), e31.

[15] Moskop, J. C., Geiderman, J. M., Hobgood, C. D., et al.: Emergency physicians and disclosure of medical errors. Ann. Emerg. Med., 2006, 48(5), 523-531.

[16] Garbutt, J., Brownstein, D. R., Klein, E. J., et al.: Reporting and disclosing medical errors: pediatricians' attitudes and behaviors. Arch. Pediatr. Adolesc. Med., 2007, 161(2), 179-185.

[17] O'connor, E., Coates, H. M., Yardley, I. E., et al.: Disclosure of patient safety incidents: a comprehensive review. Int. J. Qual. Health Care, 2010, 22(5), 371-379.

[18] Hobgood, C., Tamayo-Sarver, J. H., Elms, A., et al.: Parental preferences for error disclosure, reporting, and legal action after medical error in the care of their children. Pediatrics, 2005, 116(6), 1276-1286. 
[19] Witman, A. B., Park, D. M., Hardin, S. B.: How do patients want physicians to handle mistakes? A survey of internal medicine patients in an academic setting. Arch. Intern. Med., 1996, 156(22), 2565-2569.

[20] Blendon, R. J., DesRoches, C. M., Brodie, M., et al.: Views of practicing physicians and the public on medical errors. N. Engl. J. Med., 2002, 347(24), 1933-1940.

[21] Gallagher, T. H., Lucas, M. H.: Should we disclose harmful medical errors to patients? If so, how. J. Clin. Outcomes Manag., $2005,12(5), 253-259$

[22] Wu, A. W., Folkman, S., McPhee, S. J., et al.: Do house officers learn from their mistakes? Qual. Saf. Health Care, 2003, 12(3), 221-226.

[23] Mavroudis, C., Mavroudis, C. D., Naunheim, K. S., et al.: Should surgical errors always be disclosed to the patient? Ann. Thorac. Surg., 2005, 80(2), 399-408.

[24] Mazor, K. M., Reed, G. W., Yood, R. A., et al.: Disclosure of medical errors: what factors influence how patients respond? J. Gen. Intern. Med., 2006, 21(7), 704-710.

[25] Mazor, K. M., Simon, S. R., Gurwitz, J. H.: Communicating with patients about medical errors: a review of the literature. Arch. Intern. Med., 2004, 164(15), 1690-1697.

[26] Vincent, C., Phillips, A., Young, M.: Why do people sue doctors? A study of patients and relatives taking legal action. Lancet, 1994, 343(8913), 1609-1613.

[27] Gallagher, T. H., Studdert, D., Levinson, W.: Disclosing harmful medical errors to patients. N. Engl. J. Med., 2007, 356(26), 2713-2719.

[28] Hoy, E. W.: Disclosing medical errors to patients. Ear Nose Throat J., 2006, 85(7), 410-412

[29] Wojcieszak, D., Banja, J., Houk, C.: The sorry works! Coalition: making the case for full disclosure. Jt. Comm. J. Qual. Patient Saf., 2006, 32(6), 344-350.

[30] Boothman, R. C., Blackwell, A. C., Campbell, D. A. Jr., et al.: A better approach to medical malpractice claims? The University of Michigan experience. J. Health Life Sci. Law, 2009, 2(2), 125-159.

[31] Kachalia, A., Kaufman, S. R., Boothman, R., et al.: Liability claims and costs before and after implementation of a medical error disclosure program. Ann. Intern. Med., 2010, 153(4), 213-221.

[32] Berkhof, M., van Rijssen, H. J., Schellart, A. J., et al.: Effective training strategies for teaching communication skills to physicians: an overview of systematic reviews. Patient Educ. Couns., 2011, 84(2), 152-162.

[33] Aspegren, K.: BEME Guide No. 2: Teaching and learning communication skills in medicine - a review with quality grading of articles. Med. Teach., 1999, 21(6), 563-570.

[34] Stroud, L., Wong, B. M., Hollenberg, E., et al.: Teaching medical error disclosure to physicians-in-training: a scoping review. Acad. Med., 2013, 88(6), 884-892.

[35] Group, D. W.: Canadian Disclosure Guidelines: Being open with patients and families. 2011. http://www.patientsafetyinstitute. $\mathrm{ca} / \mathrm{en} /$ toolsResources/disclosure/Pages/default.aspx

[36] McLennan, S., Rich, L. E., Truog, R. D.: Apologies in medicine: Legal protection is not enough. Can. Med. Assoc. J., 2015, 187(5), E156-E159.

[37] Hannawa, A. F., Beckman, H., Mazor, K. M., et al.: Building bridges: future directions for medical error disclosure research. Patient Educ. Couns., 2013, 92(3), 319-327.

[38] Ryll, N. A.: Living through litigation: Malpractice stress syn drome. J. Radiol. Nurs., 2015, 34(1), 35-38.

(Pilling János dr., Budapest, Nagyvárad tér 4., 1089 e-mail: pilling.janos@med.semmelweis-univ.hu)

\section{FELHÍVÁS}

\section{A Magyar Thrombosis és Haemostasis Társaság XIII. Országos Kongresszusát 2016. október 13-15. között tartja. Helyszín: Visegrád - SILVANUS HOTEL és rendezvényközpont} Jelentkezés, illetve előadáscim és kivonat beküldési határideje: 2016. május 16.

Részletek a www.haemostasis.hu honlapon olvashatók, vagy az alábbi elérhetőségeken lehet érdeklődni:

\section{Dr. Kolev Kraszimir}

Semmelweis Egyetem, Orvosi Biokémiai Intézet

1094 Budapest, Tüzoltó u. 37-47.

Telefon: (06-1) 459-1500/60035-ös mellék; Fax: (06-1)267-0031

e-mail: kolev.krasimir@med.semmelweis-univ.hu 